\title{
IMPLEMENTASI MASSLAHAH DALAM KEGIATAN EKONOMI SYARIAH
}

\author{
Rizal Fahlefi \\ Program Studi Perbankan Syariah STAIN Batusangkar \\ J1. Jenderal Sudirman No. 137, Lima Kaum Batusangkar \\ e-mail: rizalfahlefi735@yahoo.co.id
}

\begin{abstract}
In terms of Islamic laws, anything that concern with faith (aqidab), worship ('ibadah) dan deed (muamalah) are basically aimed at ensuring safety in the world and hereafter as well. maslahah is the most important concept in developing economy and the principles of maslabah in economic field have been taken as guidance in order to achieve maqasid syariah. Obeying sharia laws is the way to realize maslabah. The implementation of maslahah in economy can be viewed from various activities of mankind in carrying out practices in economy which develop continuously and innovatively, such as in market mechanism, establishment of hisbah institution, productive divine tax (zakat), the presence of sharia financial institution, and so forth.
\end{abstract}

Kata kunci: maṣlaḥah, maqāṣid syarī'ah, implementasi

\section{PENDAHULUAN}

A jaran Islam mencakup seluruh aspek kehidupan manusia. Syariat Islam dibangun untuk tujuan yang sangat mulia, yakni untuk merealisasikan kemaslahatan manusia baik di dunia maupun di akhirat. Asy-Syatibi (1997: 5) menyatakan bahwa pelembagaan syariat Islam hanya bertujuan untuk kemaslahatan manusia baik untuk kebahagiaan hidup di dunia maupun kebahagiaan hidup di akhirat. Sebagai benang merah dari pernyataan tersebut, dapat dikatakan bahwa tujuan syariat Islam adalah untuk kemaslahatan umat manusia (Chamid, 2000: 279).

Alquran dan sunnah telah memberi penekanan terhadap fleksibelitas syariat Islam dan memastikan kesesuaian penerapannya dalam kehidupan manusia. Dengan demikian seluruh aturan syariat Islam harus sejalan dengan prinsip mașlahah sehingga segala tujuan yang diinginkan dapat dicapai dengan baik dan sempurna.

Salah satu aspek kehidupan manusia yang mendapat perhatian khusus dalam hal penerapan konsep mașlahah adalah aspek ekonomi. Karena aktivitas ekonomi merupakan bagian yang tidak terpisahkan dalam kehidupan manusia, maka prinsip maṣlahah dalam ekonomi Islam bukanlah sekedar kajian teori tetapi perlu diimplementasikan dengan metode yang benar. Tulisan ini akan 
mengupas tentang implementasi mașlahah dalam ekonomi Islam yang akan menguraikan tentang pengertian mașlahah, pembagian mașlahah, dan implementasi mașlahah dalam aktivitas ekonomi.

\section{KONSEP MAṢLAHAH}

Menurut istilah, mașlahah adalah mendatangkan segala bentuk kemanfaatan atau menolak segala kemungkinan yang merusak. Manfaat adalah ungkapan dari keseluruhan kenikmatan yang diperoleh dari usaha yang telah dilakukan dan segala hal yang masih berhubungan dengan manfaat tersebut, sedangkan kerusakan adalah keseluruhan akibat yang merugikan dan menyakitkan atau segala sesuatu yang ada kaitannya dengan kerusakan tersebut. Maṣlaḥah adalah apa yang kembali kepada kokohnya kehidupan manusia dan kehidupan yang sempurna. Menarik kemaslahatan dan membuang halhal yang merusak dalam kehidupan bisa juga disebut dengan melaksanakan kehidupan di dunia untuk kehidupan di akhirat. Penerapan mașlahah dan mafsadah tidak ada yang murni, ukurannya ditentukan oleh kekuatan yang mendominasi dan banyaknya aktifitas yang dikerjakan. Jika mașlahah lebih banyak dan kuat maka disebut mașlahah, sebaliknya jika mafsadahnya yang lebih banyak dan lebih kuat maka masuklah pada kelompok mafsadah (Asy-Syatibi, 1997: 20).

Menurut Al-Fasi (1993: 50) mașlahah adalah tujuan akhir yang ingin dicapai oleh syariat dan ragam rahasia di balik setiap ketetapan dalam syariat Islam tersebut. Makna syariat adalah hukum yang ditetapkan oleh Allah bagi hambaNya tentang urusan agama, baik berupa ibadah atau mu 'àmalah, yang dapat menggerakkan kehidupan manusia (Al-Qaradhawi, 2007: 12). Sementara Al-Ghazali menyatakan bahwa mașlahah adalah penjagaan terhadap tujuan dari syariat Islam dan tujuan dari syariat Islam terdiri dari lima hal yaitu penjagaan terhadap agama, jiwa, akal, keturunan dan harta (Shalihin, 2010: 498). Dengan demikian, apa saja yang menjamin terjaganya kelima pokok tujuan syariat tersebut dinamakan dengan mașlahah dan setiap perkara yang luput darinya disebut mafsadah/kerusakan (AlGhazali, 1997: 217). Ungkapan mașlahah dan mafsadah adalah berupa bentuk yang masih umum, yang menurut jumhur ulama adalah mengarah pada hal-hal yang berhubungan dengan urusan dunia dan akhirat. Asy-Syatibi (1997: 5) menyatakan bahwa tujuan dari diturunkanya syariat adalah untuk kemaslahatan manusia di dunia dan akhirat secara bersamaan.

Dalam pandangan Asy-Syatibi, maqāșid asy-syarīah itu mempunyai dasar paradigma yang kuat yakni $i^{\prime} t i b \bar{a} r$ al-māl, paradigma inilah yang menjadi jiwa dalam mempertimbangkan kemaslahatan dan menolak kerusakan. I'tibār al-māl adalah merupakan sebuah cara pandang yang tidak terjebak pada aspek formal suatu perbuatan, tetapi harus melihat jauh ke depan serta 
menekankan pada pentingnya untuk mengawasi dan mewaspadai dari implikasi suatu perbuatan, artinya status hukum perkara itu sangat tergantung pada dampak atau implikasi baik dan buruknya yang akan ditimbulkan (Asy-Syatibi, 1997: 110).

Mașlahah menurut Asy-Syatibi (1997: 5) dapat dilihat dari dua aspek, yakni qașd asy-Syari' dan qașd al-mukallaf. Pada aspek qașd asy-Syari' (tujuan Tuhan) mengandung empat aspek:

1. Tujuan pokok Tuhan dalam melembagakan syariat yaitu terwujudnya kemaslahatan manusia dunia dan akhirat.

2. Tujuan Tuhan melembagakan syariat sebagai sesuatu yang harus dipahami.

3. Tujuan Tuhan melembagakan syariat sebagai sesuatu hukum taklif yang harus dilakukan.

4. Tujuan Tuhan memasukan mukallaf di bawah naungan hukum syariat.

Begitu pula dari sudut qașd almukallaf, maqāșid asy-syarīah mengandung empat aspek, yaitu:

1. Pembicaraan maṣlahah, pengertian, tingkatan, karakteristik, dan relativitas atau keabsolutannya.

2. Pembahasan dimensi linguistik dari problem taklif yang diabaikan oleh juris lain. Suatu perintah yang merupakan taklif harus bisa dipahami oleh semua subjeknya, tidak saja dalam kata-kata dan kalimat tetapi juga dalam pengertian pemahaman linguistik dan kultural. Al-Syathibi mendiskusikan problem ini dengan cara menjelaskan dalālah așliyyah (pengertian esensial) dan 'umūmiyyah (bisa dipahami orang awam).

3. Analisa pengertian taklif dalam hubungannya dengan kemampuan, kesulitan dan lainlain.

4. Penjelasan aspek huzuz dalam hubungannya dengan hawa dan ta'abbudiy (Asy-Syatibi, 1997: 6).

Beberapa peneliti membagi kemaslahatan menjadi dua macam, kemaslahatan akhirat yang dijamin oleh akidah dan ibadah dan kemaslahatan dunia yang dijamin oleh muamalat. Kendati demikian tidak ditemukan korelasi yang mengharuskan untuk memperhatikan pembagian tersebut, karena pada hakikatnya segala hal yang terkait dengan akidah, ibadah, dan muamalat dalam syariat Islam menjamin segala kemaslahatan umat baik di dunia maupun akhirat.

$$
\text { Asy-Syatibi (1997: }
$$

membagi mașlahah pada tiga tingkatan, yakni:

1. Mașlahah darūriyyah (kebutuhan primer), yaitu segala sesuatu yang harus ada demi tegaknya kehidupan manusia untuk menopang kemaslahatan agama dan dunia di mana apabila maqāșid ini tidak terpenuhi, stabilitas dunia akan hancur dan rusaklah kehidupan manusia di dunia serta di akhirat mengakibatkan hilangnya keselamatan dan rahmat. Menurut Asy-Syatibi, maqāṣid ini terdiri dari lima unsur pokok, yakni agama, jiwa, keturunan, harta, dan akal. Untuk memelihara lima hal pokok inilah syariat Islam 
diturunkan seperti perlindungan terhadap hak milik dalam ekonomi.

2. Mașlahah hajiyyah (kebutuhan sekunder), adalah maqasid yang dibutuhkan untuk memberikan kemudahan dan menghilangkan kesulitan. Jika maqāssid hajiyyah ini tidak diperhatikan manusia akan mengalami kesulitan, kendati tidak akan merugikan kemaslahatan umum. Seperti ibadah shalat dan dibolehkannya akad salam (pesanan).

3. Mașlahah tahsiniyyah (kebutuhan pelengkap), adalah maqāșid yang mengacu pada pengambilan apa yang sesuai dengan adat kebiasaan yang terbaik dan menghindari cara-cara yang tidak disukai oleh orang bijak, seperti menutup aurat dalam ibadah shalat dan larangan menjual makanan yang mengandung najis.

Jika dilihat dari segi keberadaan mașlahah, ketentuan syariat membaginya atas tiga bentuk yaitu:

\section{Mașlahah mu 'tabarah}

Mașlahah mu'tabarah yaitu kemaslahatan yang didukung oleh syariat. Maksudnya, ada dalil khusus yang menjadi bentuk dan jenis kemaslahatan tersebut. Dalam kasus peminum khamar misalnya, hukuman atas orang yang meminum minuman keras dalam hadis Nabi dipahami secara berlainan oleh para ulama fikih, disebabkan perbedaan alat pemukul yang digunakan oleh Rasulullah SAW. Mașlahah menjaga agama, nyawa, keturunan (juga marū'ah), akal dan nyawa. Syara telah mensyariatkan jihad untuk menjaga agama, qișaș untuk menjaga nyawa, hukuman hudud kepada penzina dan penuduh untuk menjaga keturunan (dan juga maruah), hukuman sebatan kepada peminum arak untuk menjaga akal, dan hukuman potong tangan ke atas pencuri untuk menjaga harta.

2. Mașlahah mulghah

Mașlahah mulghah yaitu kemaslahatan yang ditolak karena bertentangan dengan hukum syara'. ini bukanlah mașlahah yang benar, bahkan hanya disangka sebagai mașlahah atau ia adalah mașlahah yang kecil yang menghalang mașlahah yang lebih besar daripadanya. Misalnya, kemaslahatan harta riba untuk menambah kakayaan, kemaslahatan minum khomr untuk menghilangkan stress, mașlahah orang-orang penakut yang tidak mau berjihad, dan sebagainya.

3. Mașlahah mursalah

Mașlahah mursalah yaitu kemaslahatan yang tidak didukung oleh dalil syariat atau naș secara rinci, namun ia mendapat dukungan kuat dari makna implisit sejumlah naș yang ada. Jadi, mașlahah ini adalah satu keadaan di mana tiada dalil khas daripada syara" yang mengi'tibarkannya dan tidak ada hukum yang telah di-naș-kan oleh syara' yang menyerupainya, yang mana boleh dihubungkan hukumnya melalui dalil qiyas. Tetapi pada perkara tersebut 
terdapat satu sifat yang munasabah untuk diletakkan hukum tertentu kepadanya karena ia mendatangkan mașlahah atau menolak mafsadah.

\section{IMPLEMENTASI MASLAHAH DALAM KEGIATAN EKONOMI SYARIAH}

Implementasi maṣlahah dalam kegiatan ekonomi memiliki ruang lingkup yang lebih luas jika dibandingkan dengan implementasinya dalam bidangbidang lain. Naș-naș terkait ekonomi pada umumnya bersifat global, karena itu ruang gerak ijtihadnya lebih luas. Sedikitnya naș-naș yang menyinggung masalah yang terkait dengan kebijakan-kebijakan ekonomi teknis, membuka peluang yang besar untuk mengisi kekosongan tersebut dengan mengembangkan ijtihad berdasarkan prinsip mașlahah. Berbeda halnya dengan bidangbidang lain seperti ibadah yang bersifat dogmatik. Dengan demikian, prinsip mașlahah menjadi acuan dan patokan penting dalam bidang ekonomi, apalagi jika menyangkut kebijakan-kebijakan ekonomi yang minim dengan aturan syara' yang mana terjadi kekosongan aturan hukum.

Terkait dengan hal tersebut, Ash-Shadr (2008: 108-109) mengemukakan bahwa Nabi Muhammad Saw dalam kapasitasnya sebagai otoritas yang berkuasa (waliyyul amr), bertindak atas nama Islam dengan tanggung jawab mengisi ruang kosong dalam hukum yang berlaku, sesuai dengan tuntunan situasi dan kondisi. Nabi tidak mengeluarkan aturan-aturan tersebut dalam kapasitas beliau sebagai penyampai hukum Ilahiah yang bersifat permanen dan tidak bisa direvisi, diubah, ataupun dimodifikasi. Keputusan Nabi Muhammad saw sebagai penguasa dan wali kaum Muslim dalam membuat aturan-aturan tersebut tidak bisa dipandang sebagai bagian permanen dari doktrin ekonomi Islam.

Untuk mengisi kekosongan hukum harus didasarkan kepada situasi dan kondisi yang sedang dihadapi oleh masyarakat muslim. Oleh karena itu, keputusan yang telah diambil untuk mengisi kekosongan hukum pada suatu saat dapat berubah pada kondisi yang lain. Keputusan penguasa tersebut sesuai dengan tuntutan keadaan untuk memperoleh mașlahah demi terpenuhinya kepentingan umat.

Mașlahah menjadi dasar pengembangan ekonomi syariah dalam menghadapi perubahan dan kemajuan zaman. Dengan pertimbangan mașlahah, regulasi perekonomian bisa berubah dari teks naș kepada konteks naș yang mengandung mașlahah. Implementasi mașlahah dalam kegiatan ekonomi tersebut dapat dilihat dalam berbagai aspek, seperti dalam masalah mekanisme pasar, pembentukan lembaga hisbah, zakat produktif, kehadiran lembaga keuangan syariah, dan sebagainya.

Pertimbangan

berdasarkan maslahah dalam mekanisme pasar dapat dilihat dalam kasus intervensi harga. 
Misalnya, Nabi Muhammad Saw menolak melakukan intervensi harga ketika para sahabat mendesaknya melakukan hal tersebut (Marthon, 2004: 85). Tetapi dalam situasi dan kondisi tertentu seperti terancamnya kebutuhan masyarakat, terjadinya monopoli, pemboikotan, atau terjadinya kolusi antar penjual, maka Ibnu Taimiyyah membolehkan pemerintah melakukan intervensi harga (Edwin dkk., 2007: 162-163). Sekilas kelihatan bahwa, pernyataan Ibnu Taimiyyah yang memberi peluang kepada penguasa untuk melakukan intervensi harga bertentangan dengan apa yang menjadi ketetapan Nabi Muhammad Saw. Namun, karena situasi dan kondisinya berbeda disertai dengan pergerakan harga yang telah merusak mekanisme pasar, maka intervensi harus dilakukan supaya harga tetap stabil. Adapun tujuan penguasa dalam melakukan intervensi pada saat itu, semata-mata untuk mencegah terjadinya tindak kezaliman dan atas pertimbangan kemaslahatan.

Adapun perbedaan antara mekanisme pasar Islam dengan mekanisme pasar konvensional hanya terletak pada aspek pengawasan. Sepanjang mekanisme pasar berjalan normal, mengedepankan keadilan dan tidak mengancam terpenuhinya kebutuhan minimal seluruh rakyat, maka negara dalam hal ini otoritas ekonomi tidak akan mengintervensi pasar dalam bentuk apapun. Tetapi, jika terjadi kegagalan pasar di luar sebab-sebab ketidakadilan dari pelaku pasar, otoritas negara boleh melakukan intervensi sepanjang kegagalan pasar tersebut mengancam dan merusak kebutuhan minimal rakyat. Untuk menjaga kemaslahatan dan kestabilan pasar maka dibentuklah lembaga hisbah atau regulator pasar yang berperan sebagai pengawas dalam seluruh aktivitas ekonomi yang berjalan di pasar.

Dalam hal ini, Ali Sakti (2007: 98) menyatakan bahwa, tugas lembaga hisbah/ regulator pasar bukan hanya sebatas mengawasi kegiatan-kegiatan pasar, akan tetapi juga memberikan dan menyediakan segala fasilitas yang dibutuhkan oleh pasar untuk memudahkan semua pelaku pasar. Fasilitas-fasilitas yang harus disediakan oleh lembaga hisbah antara lain berupa lahan yang memadai, transportasi, penerangan, penginapan bagi pedagang dari luar, dan semua falititas yang mendukung kelancaran transaksi pasar. Dengan demikian, keberpihakan lembaga hisbah dalam mendukung keseluruhan aktivitas yang menjadi kebutuhan para pelaku pasar merupakan bentuk mașlahah yang akan dapat menekan semua hambatan bagi siapa saja yang ingin masuk ke pasar, sehingga kestabilan mekanisme pasar dapat diwujudkan. Mașlahah dalam kebijakan pengelolaan zakat dapat dilihat dalam masalah zakat produktif. Menurut Zaim Zaidi (2006: 176), berdasarkan survey yang dilakukan oleh Public Interest Research and Advocacy Center (PIRAC) mencatat bahwa tingkat kesadaran masyarakat Muslim Indonesia dalam membayar zakat sangat tinggi, yakni 
mencapai angka 95\%. Adapun potensi zakat yang dapat dikelola secara profesional sebagaimana disampaikan oleh Didin Hafidhuddin mencapai $217 \mathrm{M}$. Tingginya tingkat kesadaran berzakat dan besarnya potensi zakat yang tersedia ternyata tidak berbanding lurus dengan manfaat yang dirasakan oleh mustahik.

Pendistribusian zakat yang dilakukan secara individu khususnya oleh para pengusaha kaya lebih dominan dalam bentuk konsumtif, seperti pembagian mukena shalat, kain sarung, beras dan minyak goreng beberapa kilo gram atau dalam bentuk uang berkisar antara Rp. 20.000,- s.d. 50.000,- yang dibagikan secara merata kepada para mustahik. Selain itu, prosesi pendistribusian zakat juga terkesan tidak manusiawi. Ratusan bahkan ribuan orang masyarakat yang datang dari berbagai penjuru daerah dan dari berbagai kelompok usia, mulai dari anak-anak, remaja, dewasa sampai kalangan orang tua. Mereka dikumpulkan pada suatu tempat terbuka untuk menerima zakat. Selama penantian tersebut, tidak sedikit yang jatuh pingsan karena tidak tahan kepanasan, ada yang lemas karena sudah lama berdiri menunggu antrian, dan tidak jarang jatuh korban sampai meregang nyawa akibat berdesak-desakan hanya untuk mendapatkan dana zakat sebesar Rp. 50.000,-.

Meskipun para mustahik selalu mendapatkan zakat, namun karena jumlah yang diterima sangat sedikit, tentu tidak akan mampu merubah kondisi ekonomi mereka. Pendistribusian zakat dengan pola konsumtif tersebut, secara tersembunyi akan memunculkan perasaan rendah diri dan ketergantungan para mustahik kepada muzakki dan mereka tidak akan pernah keluar dari belenggu kemiskinan. Sebaliknya para muzakki yang terbiasa menyalurkan zakat secara konsumtif akan menimbulkan perasaan bangga, sombong, dan ria.

Supaya dana zakat dapat memberi manfaat yang lebih besar bagi para mustahik, maka pola pendistribusian dalam bentuk konsumtif harus diminimalisir dan beralih kepada pola pendistribusian zakat produktif. Untuk tujuan mașlahah, maka perlu regulasi otoritas pemerintah dalam mewujudkan peran konstruktif zakat melalui kebijakan zakat produktif sebagai solusi untuk menanggulangi problema kemiskinan di negeri ini.

Kehadiran lembaga-lembaga perbankan dan keuangan syari'ah juga didasarkan kepada mașlahah. Perekonomian berbasis bunga/riba telah menciptakan corak interaksi keuangan menjadi kacau. Ali Sakti (2007: 230) mengungkapkan bahwa bunga membuat sistem keuangan dunia menjadi pincang, negaranegara miskin dan berkembang harus terus bergantung secara financial kepada negara maju. Sifat pre-determined return yang dimiliki bunga akan membuat perilaku para pemegang kapital cenderung menggunakan uangnya sebagai alat untuk men-generate pendapatan melalui sektor finansial daripada 
mendapatkan keuntungan melalui aktivitas produktif disektor riil

Jika ditinjau dari rasionalitas pasar, bunga atau sistem riba sebenarnya membuat mekanisme pasar menjadi tidak rasional. Dengan bunga, pasar selalu dipaksa dalam keadaan positif, semua unit usaha selalu ada dalam kondisi profit, tentu hal ini tidak mungkin. Bunga memiliki efek negatif yang begitu besar baik pada tingkat ekonomi maupun aktivitas sosial. Kinerja perekonomian terhambat, daya beli masyarakat menurun dan inflasi meningkat tajam. Ali Sakti (2007: 234), menyatakan bahwa sistem bagi hasil menawarkan solusi di mana dalam setiap usaha akan mengalami untung atau rugi, sehingga tidak rasional ketika perekonomian hanya mengadopsi satu kondisi saja dari dua kondisi ekonomi tersebut. Oleh karena itu, usaha bagi hasil harus sesuai dengan prinsip syariah, tidak diperkenankan mengandung unsur riba, judi dan gharar, dilarang memproduksi barang haram (babi dan khamr). Profit dibagi antara bank dengan nasabah secara proporsional, bank syariah dapat melakukan transaksi jual beli dengan pengusaha maupun nasabah, menggunakan skema murabahah, ijarah, istisna dan salam. Dengan demikian, keberanian otoritas pemerintah dalam mengambil kebijakan dan mengembangkan lembaga keuangan berbasis syariah di tanah air mengandung nilai mașlahah yang sangat tinggi.
Mașlahah merupakan konsep terpenting dalam pengembangan ekonomi Islam. Para ulama sepanjang sejarah senantiasa menempatkan mașlahah sebagai pinsip utama dalam syariah. Mașlahah bukan hukum tapi tujuan dari hukum itu sendiri. Mematuhi hukum syari'ah merupakan jalan untuk mencapai mașlahah. Jadi maqāṣid syarīah merupakan tujuan yang menjadi alat untuk mengukur kemaslahatan.

Implementasi mașlahah pada ekonomi dapat dilihat dalam aktivitas kegiatan ekonomi yang selalu berkembang. Penerapan mașlahah dalam perbankan terkait dengan bunga dan bagi hasil, dibolehkannya intervensi pemerintah dalam menetapkan harga, dibutuhkannya lembaga hisbah dalam mekanisme pasar yang mengedepankan nilai mașlahah, dan perlunya langkah-langkah konstruktif terkait pengelolaan zakat produktif, merupakan sebagian kecil bentuk mașlahah yang menjadi tujuan dalam ekonomi syari'ah.

\section{DAFTAR KEPUSTAKAAN}

Al-Fasi, Alal. 1993. Maqāṣid asySyarīah al-Islämiyyah wa Makārimuha, Rubat: Maktabah al-Wahdah al-arabiyyah.

Al-Ghazali. 1997. Al-Mushtasyfa Min Ilmi al-Ușūl. Juz 1. Bairut: Dār al Ihya' al Turāts al-'Araby.

Al-Qaradhawi, Yusuf. 2007. Fiqih Maqāșid Syarīah, Jakarta: Pustaka Al-Kautsar

\section{PENUTUP}


Ash-Shadr, Muhammad Baqir. 2008.

Buku Induk Ekonomi Islam. Jakarta: Zahra

Asy-Syatibi. 1997. al-Muwāāaqāt fi Ușūl asy-Syarīah, Beirut: DaralKutub al-Ilmiyyah

Chamid, Nur. 2000. Jejak Langkah Sejarah Pemikiran Ekonomi Islam. Yogyakarta: Pustaka Pelajar.

Shalihin, Ahmad Ifham. 2010. Buku Pintar Ekonomi Syari'ah. Jakarta: Gramedia Pustaka utama.

Marthon, Said Sa'ad. 2004. Ekonomi Islam di Tengah Krisis Ekonomi Global. Jakarta: Zikrul Hakim.
Nasution, Mustafa Edwin dkk. 2007. Pengenalan Eksklusif Ekonomi Islam. Cet. ke-2. Jakarta: Kencana.

Sakti, Ali. 2007. Analisis teoritis Ekonomi Islam, Jawaban atas Kekacauan Ekonomi Modren. Jakarta: AQSA-Publishing.

Zaidi, Zaim. 2006. Restorasi Zakat Sebuah Keniscayaan: Teladan dari Kaum Muslim Cape Town Afrika Selatan. Dalam Noor Aflah. 2006. Zakat dan Peran Negara. Jakarta: Forum Zakat. 